\title{
Organizational Commitment and Corporate Ethical Values: Exploring the Nexus between Employees' Psychological Contract and Firms' Ethical Behaviour in the Nigerian Insurance Industry
}

\author{
Musa Obalola (Corresponding author) \\ Faculty of Business Administration, University of Lagos \\ Akoka, Yaba, Lagos, Nigeria \\ E-mail: mobalola@gmail.com \\ Kunle Aduloju \\ Faculty of Business Administration, University of Lagos \\ Akoka, Yaba, Lagos, Nigeria \\ E-mail: ksaduloju@yahoo.co.uk \\ Folake Olowokudejo \\ Faculty of Business Administration, University of Lagos \\ Akoka, Yaba, Lagos, Nigeria \\ E-mail: kudejomrs@yahoo.com
}

Received: January 5, 2012

Accepted: February 16, 2012 Published: March 1, 2012

doi:10.5539/jms.v2n1p43

URL: http://dx.doi.org/10.5539/jms.v2n1p43

\begin{abstract}
Commitment of employees to their organisations has been one of the central research themes in organisational study. Though, many predictors of organisational commitment abound in the literature, much is however not known on how ethical behaviour in the organisation affects employees' commitment. Considering the nature of insurance services, and high potentials for ethical dilemma in the industry, this study contributes to organisational commitment literature by providing further understanding on the impact of corporate ethical values on organisational commitment in Nigeria. Underpinned by cognitive dissonance theory, the study proposes a significant relationship between the two constructs. While controlling for some demographic factors, corporate ethical values was hypothesized as a significant determinant of organisational commitment. With data from 415 managers, collected through Hunt's et al (1989) Corporate Ethical Value and Hunt's et al (1985) organisational commitment scales, the results of the multivariate analysis were presented, and discussed with managerial implications.
\end{abstract}

Keywords: Affective commitment, Balance theory, Cognitive dissonance theory, Continuance commitment, Corporate ethical values, Insurance industry, Nigeria, Normative commitment, Organizational commitment

\section{Introduction}

It would be an understatement to say that organizations desire committed employees. All organizations require employees who are committed to their vision, mission and goals in order to continue to exist and be relevant in the marketplace. Put differently, organizations need employees who accept their goals and values; willingly exert effort on their behalf; and strongly desire to remain with them (Mowday, Steers, \& Porter, 1979). Given that employees' commitment is necessary for desirable organizational outcomes such as increased sales and profitability (Brett, Cron, \& Slocum, 1995), job satisfaction (Lum, Kervin, Klark, Reid, \& Sirola, 1998), lower turnover intention (Sims \& Kroeck, 1994), and yet employees nowadays feel less obligated to their employers (Nussbaum, 1986; Mowday, 1998), call for a need to re-examine the antecedents of organizational commitment with a view to identifying why it is diminishing, and how it can be fostered within an organization. 
Past research efforts have endeavoured to establish the antecedents of organizational commitment, and have came up with many potential variables. These antecedent variables have generally revolved around three broad categories: personal characteristics, organizational structure/characteristics, and work experiences/characteristics (Meyer \& Allen, 1991). Whilst studies have empirically established antecedents in each of these categories, relatively little is known about how work and organizational characteristics are related to commitment (Mowday, 1998). More so, the predictive power of organizational ethical values on organizational commitment has relatively been understudied. Similarly, little research efforts have been directed at exploring the relationship between organizational commitment and corporate ethical values (Hunt, Wood, \& Chonko, 1989) in industries other than insurance industry. It is argued here that researching insurance industry will make interesting findings, given its proneness to ethical dilemma. Lastly, prior works have been conducted within a developed economy context thereby creating a dearth of empirical experience and literature on developing economies. The current study is therefore posited to fill these gaps.

Specifically, this study contributes to organizational commitment literature by exploring the relationship between organizational commitment and corporate ethical values in an ethically susceptible industry like insurance, and in Nigeria, a developing economy, with little or no known documented evidence. In accomplishing these objectives, the remaining part of the study is organized as follows. First, a brief review of organizational commitment and corporate ethical values literatures are considered, with a view to develop the theoretical framework and the research hypotheses. Second, the research method used in identifying the target population, establishing a representative sample, and of administering the research instruments are considered. Third, the various analyses conducted and the results are presented, and discussed with managerial implications. The final section concludes with limitations of the study and suggestions for further investigation.

\section{Literature review}

\subsection{Organizational commitment}

The question of what is organizational commitment and its determinants have generated a lot of arguments and disagreement among organizational behaviour scholars (Meyer \& Herscovitch, 2001; Bentein, Vandenberg, Vandenberghe, \& Stinglhamber 2005; Solinger, van Olffen, \& Roe, 2008). Notwithstanding the lack of consensus, there appear to be dominance of opinion that commitment sojourns along three main dimensions affective, continuance, and normative (Meyer \& Allen, 1991; Meyer \& Herscovitch, 2001; Bentein et al., 2005). In their conceptual definition, which reflects the affective component, Porter, Mowday, \& Boulin (1974) conceive organizational commitment as, "the relative strength of an individual's identification with and involvement in a particular organization". Using stronger words, and apparently building on Porter et al's (1974) definition, Meyer \& Allen (1991) define affective commitment as, "the employee's emotional attachment to, identification with, and involvement in the organization" (p. 67).

Continuance commitment, which is underpinned by the "side-bet theory", is conceptualized as the tendency to maintain membership in an organization because of the perceived cost associated with leaving (Meyer \& Allen, 1984; Meyer, Paunonen, Gellatly, Goffin, \& Jackson, 1989). Continuance commitment is attributed to Becker (1960), who described commitment as the tendency to engage in "consistent lines of activities" (p. 33) because of the perceived cost of doing otherwise (Meyer, et al., 1989). The normative view of the construct (commitment) conceives organizational commitment as a desire to maintain membership in an organization because of a strong felt moral obligation. In this instance, commitment is seen as "a function of internalized normative beliefs" (Wiener, 1982, p. 423). According to Wiener (1982), organizational commitment can be viewed as, "the totality of internalized normative pressures to act in a way that meets organizational goals and interests (p. 421).

In drawing a distinction between the normative and continuance commitment, Wiener argued, that as a person's (i.e. employee) commitment becomes stronger, there will be a stronger disposition for actions to be guided by such internalized normative standard rather than by consideration of the consequences of the actions. In order words, individuals do identify with organizational goals and interests, and continue to maintain memberships in such organizations not because they perceived doing so will be beneficial to them (continuance commitment), but because they harbour strong beliefs that doing so is the "morally right thing to do" (normative commitment).

Despite the differing conceptual views, the three components have generally been held to share a common trait, i.e., commitment is a psychological state (Allen \& Meyer, 1990) that explains employees' relationship with their organizations, and the attendant implications of decision to continue or discontinue membership in such organizations (Meyer \& Allen, 1991). The three conceptualizations are only differentiated in the literature by the nature of the psychological states. Whereas affective commitment is underpinned by a desire to be committed, 
continuance commitment is characterized by a need to be committed, while normative commitment is driven by a feeling of moral obligation to continue employment (Meyer \& Allen 1991).

Considering the compartmentalization of organizational commitment, and the mind sets that characterize each of them, one might be tempted to assume that the three are distinct and mutually exclusive. This assumption was operationalized by Allen \& Meyer (1990), who reasoned that if the three components have evolved as earlier described (i.e., different psychological state), the measures (Affective Commitment Scale - ACS; Continuance Commitment Scale - CCS; and Normative Commitment Scale - NCS) identified in the literature as measuring each should correlate with work experiences predicted to be their antecedents, and not correlate with those predicted to be antecedents of the other components (p. 5). Though the principal factor analysis and the Varimax rotation of the factor matrix revealed strongest loading of factor items under their corresponding constructs, the relationship among the three constructs however indicated that both ACS and NCS are significantly related while CCS did not correlates with either of the other two scales. Similarly, the results of the canonical correlation analysis of the antecedents of the three components of commitment and their measures indicated a shared variance between the affective commitment and normative commitment. The observed relationship between these two forms of commitment led the authors to opined that while the desire to maintain membership in an organization (affective commitment) might not be tantamount to feeling of obligation to do so, there might be reasons to believe in their co-existence. On this basis Allen and Meyer (1990) speculate, as moral obligations are internalized to form personal norms, they influence individuals' feelings about what they want to do. Alternatively, to justify behaving in accord with their desires, individual may come to accept that their actions are morally right (p. 11).

The finding that both affective and normative commitment shared some overlapped variance have also been confirmed by some studies (e.g. Ko, Price, \& Mueller, 1997; Powell \& Meyer, 2004), on account of which authors have questioned whether the two should be regarded as separate components (Ko et al, 1997; Meyer \& Herscovitch, 2001), because as it were, "feelings of what one wants [affective] to do and what one ought [normative] to do, do not seem to suggest complete independence after all (Meyer \& Allen, 1991).

Contrary to the empirical evidence (obtained from confirmatory factor analysis) in Meyer, Allen, \& Gellatly (1990), which led to the conclusion that affective commitment and continuance commitment are two distinct constructs, and thus unrelated (Meyer \& Allen, 1984), McGee and Ford (1987) had earlier established that affective and continuance commitment might not be independent of each other. Their conclusion was based on the factor analysis conducted to assess the factorial structure of the ACS and CCS, which results in CCS having two factorial structures, each of which was differentially related to ACS. Whilst the two factor solution of CCS and its differential correlation with ACS was also observed in Meyer et al. (1990), the authors however interpreted these differently.

Concerning the factorial structure of CCS, Meyer et al. (1990) concluded that the two solutions obtained suggest the existence of two distinguishable cost-based commitments, and interpreted the differential relationships with the ACS as indicating differences in the direction of influence. Whereas the negative relationship could be a reflection of negative influence of affective attachment on the tendency to claim commitment owing to lack of available alternatives, the positive relationship (between ACS and personal-sacrifice component) could be a reflection of positive influence of the recognition of cost on feelings of affective attachment (p. 719).

Given the empirical inconsistencies in operationalizing the three-component model of organizational commitment, several later studies have call for a model refinement (Meyer \& Herscovitch, 2001; Powell \& Meyer, 2004) and even a complete disregard of organizational commitment as a three-component construct (Ko et al., 1997; Solinger et al., 2008). To the effect that empirical evidence has shown only ACS to have adequate and stable psychometric properties, argument has been proposed that organizational commitment be viewed as only having affective component - a-unidimensional construct (Ko et al., 1997), as measured by the OCQ, a scale developed by Porter and associates.

Following these criticisms and observation that affective commitment is preferred as the core concept of organizational commitment (Solinger et al., 2008), the current study adopts the Porter et al's (1974), Porter, Crampon \& Smith's (1976); and Mowday et al's (1979) conceptual definition, which conceives organizational commitment as "the relative strength of an individual's identification with and involvement in a particular organization", which reflects three components (Mowday, 1998) - "a strong belief in and acceptance of the organization's goals and values; a willingness to exert considerable effort on behalf of the organization; and a strong desire to maintain membership in the organization" (Mowday et al., 1979, p. 226). 


\subsection{Corporate ethical values}

It has been argued that organization's ethical orientation can affect employees' attitude. Since this study intends to investigate the impact of organizational ethical practices on employees' work outcomes, it is considered important to conduct a brief review of organizational ethics literature. In a proposed reformulation of corporate culture, Robin and Reidenbach (1987) argued that the key to success of any corporate culture is the selection and implementation of an organisational profile identified by core values, which eventually becomes an integral part of the organisational mission. On the ethical dimension of corporate values, Hunt et al. (1989) theorised that corporate culture equals the aggregation of ethical values of individual managers, as well as the formal and informal policies of the organization on ethics (p. 79). Jansen and Von Glinow (1985) also posit that corporate ethical values are not just the underpinning of all other values relating to product and service quality, advertising content, selection of distribution channels, and treatment of customers, but also help establish and maintain the standards that describe the 'right' thing to do and the things 'worth doing'. Such ethical values/standards have been held to enhance organisational success, if widely shared among organisational members (Keeley, 1983; Koch \& Fox, 1978; Brown, 1976).

Bommer, Gratto, Gravander, and Tuttle (1987) in their theoretical model posit that the work environment can interact with several other factors to influence managers' decisions to either act ethically or unethically. The model identified corporate goals, stated policy and corporate culture as some of the organisational factors that can influence ethical decision-making. According to the authors, corporate goals can be short and long-term, with most companies emphasising the short-term goals in terms of return on investment and profitability. They argued that when short-term goals are dominant in a company's outlook, there is high likelihood of ethical concerns being subordinated. Supporting this argument, Laczniak (1983) posits that the ranks of middle managers and below are usually put under pressure with demands for results when the profit goal is dominant in a firm's short-term goals, which is interpreted that any impediment to this goal should be disregarded. In this regard, pressure from the organisation can be a significant factor in ethical decision-making (Ferrell \& Gresham, 1985).

Both stated formal and informal policies are also shown as an organisational antecedent that can influence ethical decision-making (see for example Hunt \& Vitell, 2006; Bommer et al., 1987; Ferrell \& Gresham, 1985). This policy is usually presented in the form of codes, which sensitises employees to the importance of ethical decision-making. Hunt et al. (1989) posit that organisational values "serve to convey a sense of identity to its members, enhance the stability of its social system, direct managers' attention to important issues, and guide subsequent decisions by managers" (p. 80). Using differential association theory, Ferrell \& Gresham (1985) (citing Sutherland \& Cressey, 1970) postulate that ethical/unethical behaviour is learned in the process of interacting with persons who are part of intimate personal groups or role set. Thus the extent to which the learning process results in unethical behaviour will be a function of the ratio of contact with unethical patterns to contacts with ethical patterns (p. 90). The import of this theory is that top management, and peers in the organisation can influence ethical/unethical behaviour of managers, and hence, ethical decision-making.

\subsection{Organizational commitment and corporate ethical values}

Though several predictors of organisational commitment have been identified in the literature, few of these have been directed at understanding the explanatory power of organizational ethical values. One of the earlier works to have looked at this is Hunt et al. (1989). The authors theorised that "when top managers create a corporate culture that emphasizes high ethical values, marketers' commitment to the organization will increase" (p. 80). With a sample of marketing professionals, this theoretical assumption was found to be true. The study documented that organizational commitment is significantly and substantively determined by perceptions of high corporate ethical values. This finding suggests that commitment is an organizational outcome of ethical decision-making.

Several theories have been used to explain the relationship between organizational commitment and corporate ethical values. For example, person-organization fit, social identity, cognitive dissonance theory, organizational justice theory (comprising distributive and procedural justice) etc. Of these, cognitive dissonance theory is adjudged to be more relevant in achieving the main objective of this study. Both the cognitive dissonance theory, and another version of it - balance theory are considered in this study. According to cognitive dissonance theory (see Koh \& Boo, 2001 for a discussion of this theory), the individual usually exerts considerable effort to minimize dissonance in their environment, which put in an organizational context, implies employees strive and desire congruence between their ethical standards and that of their organization. Where dissonance or incongruence is perceived, this will lead to dissatisfaction (Viswesvaran, Deshpande, \& Joseph, 1998) and 
employees would want to minimize this. The minimization could lead to withdrawal and resignation from the organisation (Jansen \& Von Glinow, 1985). Drawing inspiration from Heider's (1946) balance theory (Note 1), a version of cognitive dissonance theory, Viswesvaran et al. (1998) extrapolate that:

In a set of three entities - individual and attitude towards two entities, if the individual is to have both attitude positive, then the two entities should be positively related. Since most individuals strive to be ethical (by their own decision rule) and successful, we have positive relationship between the individual and perceptions of success and perceptions of support for ethical behaviour. It is likely that top managers reflect success in most organizations. Now, if there is a perception that top managers in an organisation do not support ethical behaviour, a dissonance results. This dissonance contributes to dissatisfaction with existing conditions in the work place (p. 367).

What can be deduced from Heider's (1946) balance theory, and Viswesvaran et al's (1998) extrapolation, using logic, which seems to have inspired Heider's postulation is that if a manager's job causes him to behave unethically (due to pressure from superiors), and the manager does not like unethical behaviour, then the manager will not like his job, because it causes him to be unethical. This assumption is verifiable, and a number of works have tried to empirically explore the relationship between organisational commitment and corporate ethical values (see Viswesvaran et al., 1998; Schwepker Jr., 2001; Koh \& Boo, 2001). Findings from these works seem to suggest that where a manager experiences moral conflict due to lack of fit between his personal ethical standard, and that of the organisation, but did not resign, this tends to lead to reduced job satisfaction (Koh \& Boo, 2001) and lower commitment (Paterson, 2003; Rozen, De Pelsmacker, \& Bostyn, 2001). Similarly, Schwepker Jr. (2001) found that greater job satisfaction is associated with stronger organisational commitment, and the higher the perceived level of organisational ethical climate, the higher the level of organisational commitment, and the lower the intention to leave the organisation.

\subsection{Development of research hypotheses}

Porter et al. (1974) identified three dimensions of organisational commitment in their affective conceptualization of commitment: (1) strong belief in and acceptance of organisation's goals and values; (2) willingness to exert considerable effort on behalf of the organisation; and (3) strong desire to maintain membership in the organisation. The results of Weeks and Nantel (1992) seem to suggest that employees in firms with well-communicated codes of ethics are more moderately successful and satisfied with their job (p. 757). Schwepker (2001) also empirically established that stronger enforcement of codes of ethics is positively related to organisational commitment (see also, Cullen, Parboteeaah, \& Victor, 2003; Vitell \& Davis, 1990; Koh et al., 2004). Schwatz (2001) reported that one of the major reasons for not complying with codes of ethics was dissatisfaction with one's job (p. 254). Somers (2001) documented that firms with formal codes of ethics enjoy high level of employee commitment than firms without formal codes of ethics (p. 190). Viswesvaran et al. (1998) empirically established that individuals who perceive the top management in their organisations to be supportive of ethical behaviour are more satisfied with their jobs. Hunt et al. (1989), in a survey of 1246 marketing professionals also found corporate ethical values to be significant and substantial predictors of organisational commitment. Given that ethical codes of conduct enhance ethical decision-making, positive work attitudes and higher levels of organisational commitment, it would be reasonable to propose a positive relationship between organizational commitment and corporate ethical values. However, because of the widely reported unethical practices (e.g., Oguninde, 1995; Ayorinde, 2000) in the industry context of this study, no direction is given to the hypothesized relationship. Thus it is proposed.

\section{Hypothesis 1}

$\mathbf{H}_{\mathbf{1}}$ : There is a significant relationship between organisational commitment and perceived corporate ethical values.

Following from the empirical evidence cited above, and the hypothesized relationship, irrespective of the direction of this relationship, there is a strong reason to believe that corporate ethical values will also significantly predict the extent to which employees in the insurance industry are bound to their organizations. Again, it is proposed as follows:

\section{Hypothesis 2}

$\mathbf{H}_{2}$ : Corporate ethical values will be a significant determinant of organisational commitment.

\subsection{Control variables}

Commitment literature has shown several variables as antecedents and predictors of the three forms of commitment (i.e. affective, continuance, and normative), under three broad categorization of personal 
characteristics, organizational characteristics, and work experiences. Fairly central to all of them among the personal variables are age, tenure, and position, education (see for example, Glisson \& Durick, 1988; Angle \& Perry, 1981; Hrebiniak \& Alutto, 1972). To therefore assess the predictive power of corporate ethical values on organizational commitment, age, length of service, and position in the organization were all included as control variables. To ensure that these variables are amenable to regression analysis, they were re-coded into dichotomous variables. Age was re-coded as young and old; position in the organisation to top management and lower management; and length of service to short and long. Thus, hypotheses 3 and 4 is proposed,

\section{Hypothesis 3}

$\mathbf{H}_{3}$ : There is a significant relationship between age, length of service, position and organisational commitment.

\section{Hypothesis 4}

$\mathbf{H}_{4}$ : controlling for age, length of service, and position, corporate ethical values will be significant determinants of organisational commitment.

\section{Method}

\subsection{Data collection}

The respondents of this study were randomly selected through a multi-stage cluster sampling from the list of managers working in the Nigerian insurance industry. Each respondent was required to complete the instrument of the study, which comprises sets of questions measuring organizational commitment and corporate ethical values, in addition to their demographic information. From the demographic information supplied in the questionnaires, $58 \%$ of those who responded were male managers, while $41 \%$ were female managers, indicating a slightly higher percentage of male to that of female respondents. The majority of the respondents were middle-aged $(60 \%)$, followed by young managers $(21 \%)$, and then the older managers, whose age range between 46 and 65 years.

Most of the respondents were also well educated, with $92 \%$ of them having at least higher national diploma (HND), which is an equivalent qualification to university degree. Only about $7 \%$ of respondents were less educated, with qualifications ranging from college to ordinary national diploma (OND). Of the $90 \%$ well educated respondents, $28 \%$ of them have a first degree, about $15 \%$ have additional postgraduate qualifications, and $11 \%$ have professional qualification, while those who were classified as others have a combination of at least high school qualification and professional qualifications. So in terms of ability to understand and complete the instrument, majority of the respondents were quite educationally and professionally competent. Regarding length of service, the majority of the respondents have worked for a minimum of 6 years $(53 \%)$ for their organisations and the industry as a whole, while those with less years of service range from less than 1 year to 5 years $(46 \%)$. This indicates that an average manager who responded is quite familiar with the practice in the industry.

Reflecting the pyramidal structure of managers in any organisation, the distribution of the respondent managers cluster around the first line and middle managers, with $45 \%$ and $41 \%$ respectively, while top managers only constitute $12 \%$ of the total sample. With regard to classification of respondents by department, the cluster revolved around managers in the underwriting (36\%), and marketing $(21 \%)$ departments, while $12 \%$ and $3 \%$ were in claims and product development. The categories of those classified as others range from those in finance, IT, actuarial services, reinsurance, and public relations departments, and constitute $27 \%$ of the total respondents. The structure of the industry broadly comprises insurance companies, reinsurance companies, pension fund, loss adjusters, and brokers. By types of business underwritten therefore, $39 \%$ of the respondents were in general business, $35 \%$ in composite (those who underwrite both life and general business), $10 \%$ in life business, and $14 \%$ were in companies who are reinsurers, pension fund administrators, loss adjusters, and brokers by the above classification.

\section{Measures}

\subsection{Organisational commitment scale}

The organizational commitment scale was developed by Hunt, Chonko, and Wood (1985) to capture the extent of managers' 'psychological bond' to their organisations, which invariably propels them to act in manners consistent with the organisational goals. The scale is unidimensional, with 4 items and specifically measures the extent to which managers are willing to change their jobs for certain reasons reflected in the scale items, such as change of job for higher pay, more creative freedom, more status, and more friendly environment and people. Based on the adopted conceptual definition of affective commitment, that committed employees believe in and 
accept organisational goals and values, are willing to remain with the organisations, and are willing to provide considerable effort on its behalf (Mowday et al., 1979), the scale is utilised in this study to measure the proposition that managers who perceived values congruence between their ethical standard and those of their organizations, who perceived top management in their organizations supporting ethics, by rewarding ethical conducts and sanctioning unethical behaviour, will be show higher level of commitment.

\subsection{Corporate ethical values scale}

Earlier discussed is the proposition that employees are strongly influenced by settings within their organisations (Trevino, 1986; Wotruba, 1990), and are likely to develop perceptions about the ethical work climate in such organisations on the basis of policies, practices, and procedures related to ethics (Victor \& Cullen, 1988). To capture this construct, Hunt et al's (1989) developed the corporate ethical value (CEV) scale to examine the possible impact of corporate ethical values on the level of managers' commitment to their organizations. This scale was also adopted in this study. Concerned with the broader issues of how organisations show interest in ethics and act ethically, CEV was developed with the intent of encapsulating three broad-based perceptions, namely:

- The extent to which employees perceive that managers are acting ethically in their organisation.

- $\quad$ The extent to which employees perceive that managers are concerned with the issues of ethics in their organisation.

- $\quad$ The extent to which employees perceive that ethical (unethical) behaviour is rewarded (punished) in their organisation.

The scale was established as a unidimensional scale by Hunt et al. (1989) and shown to have high reliability. Scale items for both measures were measured on a 7 -point Likert format $(1=$ strongly disagree and $7=$ strongly agree).

\section{Results}

\subsection{Psychometric properties of the measuring scales}

In order to assess the adequacy and the stability of the instrument, both the commitment and CEV scale were subjected to factor analysis and reliability checks.

Organizational Commitment Scale: The 4 items that made up this scale were factor analyzed using principal component analysis (PCA) with SPSS Version 15. Suitability of factor analysis for the sample was confirmed by a Kaiserr-Meyer-Olkin (KMO) value of .74, which met the minimum required value (.6) for factor analysis (Kaiser, 1970, 1974), while Bartlett's Test of Sphericity (Bartlett, 1954) was highly significant $(\mathrm{p}<.000)$, suggesting that the correlation matrix obtained in the analysis is not an identity matrix. The correlation matrix also revealed a reasonable number of coefficient values of above .3. The PCA revealed one Eigenvalues exceeding 1, explaining 54.2 of the variance. The inspection of the screeplot confirmed the unidimensional nature of the scale. The results of the parallel analysis also supported this one-factor solution, which showed the only component having Eigenvalues exceeding the corresponding criterion values for a randomly generated data matrix of the same size (4 variables x 415 respondents). The one-factor solution explained $54.2 \%$ of the variance. Due to the unidimensional nature of the scale, rotation of the factors could not be performed. This result is consistent with that of the authors of the scale (e.g. Hunt et al., 1985). The unrotated factor items are presented in table 1 .

The internal consistency check of the scale yielded a Cronbach alpha value of 0.71 , which compares favourably with earlier established ones (e.g. Hunt et al., 1985 - $\alpha$ : 0.85; Hunt et al., $1989-\alpha$ : 0.87; Vitell \& Paolillo, 2004 $\alpha: 0.79$; Vitell \& Hidalgo, 2006 - $\alpha: 0.79$ ).

\section{Insert table 1 here}

Corporate Ethical Values (CEV) Scale: The 5 items that made up the CEV scale were also subjected to principal component analysis (PCA) with the same version of SPSS. Kaiserr-Meyer-Olkin (KMO) value of approximately .60 confirms the suitability of the sample for factor analysis. Bartlett's Test of Sphericity (Bartlett, 1954) was also highly significant $(\mathrm{p}<.000)$. The correlation matrix revealed a reasonable number of coefficient values of above .3. The PCA showed two Eigenvalues exceeding 1, explaining $36 \%$ and $31 \%$ of the variance respectively. The inspection of the screeplot revealed a clear break after the second component. The results of the parallel analysis supported this two-factor solution, which showed the 2 components having Eigenvalues exceeding the corresponding criterion values for a randomly generated data matrix of the same size. 
The two-factor solution explained a total of $67 \%$ of the variance, with Component 1 contributing $36 \%$ and, Component 2 contributing $31.5 \%$. To obtain a clear interpretation of the components, Varimax rotation with Kaiser Normalisation indicates a simple and clear structure (Thurstone, 1947), without any cross-loading of the items. The rotated and unrotated factor items are shown in table 2. Strong support was found in the literature (Hunt, Chonko, \& Wilcox 1984) to maintain the two-factor solution, even though some studies have validated the CEV as a unidimensional construct (e.g. Hunt et al., 1989). The first dimension was labelled 'top management support for ethics', while the second dimension was labelled 'managers are acting ethically'.

Insert table 2 here

In the early validation of the CEV scale, a Cronbach alpha value of 0.78 was reported by the authors. Later reliability checks indicated Cronbach alpha values of 0.83 (Vitell et al., 2003), and 0.67 (Vitell \& Paolillo, 2004). The current study establishes the CEV scale as a two-dimensional scale, with Cronbach alpha values of 0.65 and 0.72 respectively. It is argued here that the two factor solution is consistent with the initial development of the scale (Hunt et al., 1984). The Hunt et al's (1984) study used two scales to measure ethical problems in marketing (ethical problem scale and ethics-related top management actions scale), and these scales were combined in their later study (Hunt et al 1989) as a unidimensional scale (corporate ethical value scale - CEV).

The two-factorial solution obtained from the factor analysis of the CEV in the current study is therefore a reflection of the underlying constructs for which the scale was initially designed to measure. Very recently, a study by Singhapakdi, Gopinath, Marta, and Carter (2008), also established the CEV scale as a two-dimensional construct, using both exploratory factor analysis (EFA) and confirmatory factor analysis (CFA). The results revealed the same pattern of factor loadings as the ones obtained in this study. When attempt was made to assess the reliability of the CEV as a unidimensional scale, the Cronbach alpha value was 0.52 and the inter-item correlation matrix revealed some negative values indicating that the items were not measuring the same underlying characteristic.

\subsection{Descriptive statistics and correlations}

Descriptive statistics of the focal variables and the demographic ones, correlations, and Cronbach alpha values are shown in table 3. Results of the correlation analysis confirmed nearly all the proposed relationships, and were significant. With the exception of length of service, all other variables were significantly correlated with the criterion variable, giving full support to hypotheses 1 , and partially supporting hypothesis 3 . Of these relationships, top management support for ethics has the highest correlation $(r=0.346, n=414, p<0.01)$ with organization commitment. Since no direction was specified in the predicted relationships, the results indicated that top management support for ethics and position were negatively correlated with organizational commitment, while managers are acting ethically and age positively correlated. The relationships established between the dependent variable and the three control variables were consistent with those established in prior studies.

Insert table 3 here

\subsection{Regression models}

The results of the first regression model as shown in table 4 indicate that both dimensions of corporate ethical values were significant predictors of organizational commitment thereby fully supporting hypothesis 2 , which states that corporate ethical values will be significant determinant of organizational commitment. The two CEV variables combined together explained $16 \%$ of variance in organizational commitment. Of this contribution, top management support for ethics contributed the highest variance, with a part correlation coefficient of -0.353 , indicating $12 \%$ contribution, while a part correlation coefficient of 0.209 indicates that managers are acting ethically only contributed $4 \%$ of the explained variance in organizational commitment. Though both variables significantly predicted the criterion variable, the directions of the influence were however different. Whereas managers are acting ethically positively determines organizational commitment, top management influence was however in the negative direction. Though this result seems paradoxical, it is nevertheless not explainable considering that both top management and peers in the organization do act as referent groups, and it not unlikely to have differing ethical standard between the two.

Insert table 4 here

\section{Discussion and managerial implications}

The findings in this study lend support to prior ones that organizational ethical standard do affects employees' level of commitment (Hunt et al., 1989; Valentine \& Barnett, 2003). For example, while the professionals who constituted subjects in the current study and that of Hunt et al. (1989) differ, the level of explained variance were however comparable. In Hunt et al. (1989), a R squared value of 0.17 was reported as the amount of variance 
explained by corporate ethical values alone, while this study establishes a $\mathrm{R}$ squared value of 0.16 for the same independent variable. Similarly, a study by Valentine and Barnett (2003) showed corporate ethical values as the only variable that uniquely contributed to explaining the variance in organizational commitment. Though, age, length of service (otherwise called tenure in prior research), and position are used here only as control variables, the results obtained are not far from those in extant studies that have established these variables as antecedents and correlates of organizational commitment (e.g. Hrebiniak \& Alutto, 1972; Morris \& Sherman, 1981; Glisson \& Durick, 1988).

Though, the results indicate corporate ethical values as substantial significant determinant of organizational commitment, but how do one interpret the directionality of this prediction. From the outset, and in recognition of the nature of the industry being studied, no direction of the proposed relationships was specified, but with differential association of the two components of corporate ethical values to organizational commitment, two possible interpretations are possible. Though admittedly speculative, the positive relationship with managers are acting ethically dimension suggests that respondents perceived that their peers in the organization are concerned about ethical practices, and did reflect in their conducts. In this instance, a high level of perceived ethicality of peers in the organization is associated with a high level of organizational commitment. By the same token, the negative relationship with top management support for ethics does suggest that the ranks of top managers in the industry might not be as ethically conscious as their subordinates. As suggested by scholars, top management could only be "talking the talk and not walking the walk". This means they actually talk about ethics but fall short in practicing its ideals. While study has shown that a high percentage of these insurance companies do have codes of ethics (Obalola, 2008), this might just simply be a case of window dressing, while the codes largely remained unenforced. As proposed by Peterson (2003), notwithstanding "the widespread adoption of ethics codes, management in some organizations may be inclined to pressure employees to compromise their personal ethical standards when the results benefit the organization" (p. 568).

To the extent that corporate ethical values significantly enhance employees' commitment, one of the practical implications of these findings is that organizations who desire positive organizational outcomes, must consciously promote high ethical conducts by rewarding/sanctioning ethical/unethical behaviours. Top management must particularly serve as a referent group in the organization if such desirable outcomes must be attained. As observed by Hunt et al, "top managers should define, refine, evaluate, communicate, and thus institutionalize the ethical principles underling their policies, practices, and goals" (p. 88).

Given that loyal employees are instrumental to developing higher quality customer relationships, and higher customer loyalty (Reichheld (Note 2), 1996), the leadership in the industry might be shooting itself in the leg if it falls short of institutionalizing high ethical standard, which could bring about this realization. This realization which was argued to lead to higher economic performance is desperately needed in the insurance industry if it is to reap the benefits of the just concluded recapitalization process.

\section{Limitations, suggestion for further studies, and conclusion}

Can the findings in this study be generalized to the entire Nigerian insurance industry? The careful procedures follow in administering the research instruments, and the subsequent analyses do give some level of confidentiality in this regard. However, a higher sampling frame that takes the geographical zone of the country into consideration in any future research could give further validity to the results obtained in this study. While the findings reported here could be true of the insurance industry, the same may not hold for other industries. This may not hold even for the banking industry that share similar traits with insurance. Further studies might be necessary to replicate the findings in these other industries. To the effect that this study only investigates the effect of corporate ethical values on organizational commitment, other relating variables, such as job satisfaction, and turnover intension should be included in future research to ensure a more robust findings.

Driven by paucity of research and empirical evidence on the possible effects of organizational ethical values on organizational commitment in insurance industry and developing countries, this study pursued this objective in the Nigerian insurance industry and found corporate ethical values to be significant determinants of organizational commitment. Notwithstanding the controlling effects of some personal antecedent variables, corporate ethical values still remain a substantive significant predictor of organizational commitment. The findings led to the conclusion that if the Nigerian insurance industry desire positive organizational outcomes that are associated with organizational commitment, concerted effort must be made to institutionalize and promote high ethical standards, which meets the moral aspirations of its employees. 


\section{References}

Allen, N. J., \& Meyer, J. P. (1990). The Measurement and Antecedents of Affective, Continuance and Normative Commitment to the Organization. Journal of Occupational Psychology, 63, 1-18. http://dx.doi.org/10.1111/j.2044-8325.1990.tb00506.x

Ayorinde, R. O. (2003). Concentration Patterns in the Insurance Market in Nigeria. The Nigerian Journal of Risk and Insurance, 4(1), 36-53.

Bartlett, M. S. (1954). A note on the Multiplying Factors for Various Chi Square Approximations. Journal of the Royal Statistical Society, 16(Series B), 296.

Becker, H. S. (1960). Notes on the Concept of Commitment. American Journal of Sociology, 66, 32-40. http://dx.doi.org/10.1086/222820

Bentein, K., Vandenberg, R. J, Vandenberghe, C., \& Stinglhamber, F. (2005). The Role of Change in the Relationship between Commitment and Turnover: A Latent Growth Modelling Approach. Journal of Applied Psychology, 90(1), 468-482. http://dx.doi.org/10.1037/0021-9010.90.3.468

Bommer, M., Gratto, C., Gravander, J., \& Tuttle, M. (1987). A Behavioural Model of Unethical Decision-making. Journal of Business Ethics, 6(4), 265-280.

Brett, J. F., Cron, W. L., \& Slocum, J. W. Jr. (1995). Economic Dependency on Work: A Moderator of the Relationship between Organizational Commitment and Performance. Academy of Management Journal, 38, 261-271. http://dx.doi.org/10.2307/256735

Brown, M. (1976). Values: A Necessary but Neglected Ingredient of Motivation on the Job. Academy of Management Review, 1, 1523.

Cullen, J. B., Parboteeaah, K. P., \& Victor, B. (2003). The Effects of Ethical Climates on Organisational Commitment: A Two-Study Analysis. Journal of Business Ethics, 46(2), 127-141. http://dx.doi.org/10.1023/A:1025089819456

Ferrell, O. C., \& L. G. Gresham (1985). A Contingency Framework for Understanding Ethical Decision-making in Marketing. Journal of Marketing, 49(3), 87. http://dx.doi.org/10.2307/1251618v

Glisson, C., \& Durick, M. (1988). Predictor of Job Satisfaction and Organizational Commitment in Human Service Organizations. Administrative Science Quarterly, 33, 61-81. http://dx.doi.org/10.2307/2392855

Heider, F. (1946). Attitudes and Cognitive Organisation. Journal of Psychology, 21, 107-112. http://dx.doi.org/10.1080/00223980.1946.9917275

Hrebiniak, L. G., \& Alutto, J. A. (1972). Personal and Role-Related Factors in the Development of Organizational Commitment. Administrative Science Quarterly, 17, 555-573. http://dx.doi.org/10.2307/2393833

Hunt, S. D., \& Chonko, L. B. (1984). Marketing and Machiavellianism. Journal of Marketing, 48, 30. http://dx.doi.org/10.2307/1251327

Hunt, S. D., \& Vitell, S. J. (2006). The General Theory of Marketing Ethics: A Revision and Three Questions. Journal of Macromarketing, 26(2), 143. http://dx.doi.org/10.1177/0276146706290923

Hunt, S. D., and Vitell, S. J. (1986). A General Theory of Marketing Ethics. Journal of Macromarketing, 6(1), 5. http://dx.doi.org/10.1177/027614678600600103

Hunt, S. D., Chonko, L. B., \& Wilcox, J. B. (1984). Ethical Problems of Marketing Researchers. Marketing Research, 21(3), 309-324. http://dx.doi.org/10.2307/3151607

Hunt, S. D., Chonko, L. B., \& Wood, V. R. (1985). Organisational Commitment and Marketing. Journal of Marketing, 49, 112-126. http://dx.doi.org/10.2307/1251181

Hunt, S. D., Wood, V. R., \& Chonko, L. B. (1989). Corporate Ethical Values and Organisational Commitment in Marketing. Journal of Marketing Science, 53(3), 79-90.

Janson, E., \& Von Glinow, M. (1985). Ethical Ambience and Organisational Reward Systems. Academy of Management Review, 10(4), 814.

Keeley, M. (1983). Values in organisational Theory and Management Education. Academy of Management Review, 8(3), 376-386.

Keiser, H. F. (1970). A Second-generation Little Jiffy. Psychometrika, 35, 401. http://dx.doi.org/10.1007/BF02291817 
Keiser, H. F. (1974). An Index of Factorial Simplicity. Psychometrika, 39, 31. http://dx.doi.org/10.1007/BF02291575

Ko, J. W., Price, J. L., \& Mueller, C. W. (1997). Assessment of Meyer and Allen's Three-Component Model of Organizational Commitment in South Korea. Journal of Applied Psychology, 82, 961-973. http://dx.doi.org/10.1037/0021-9010.82.6.961

Koch, J. L., \& Fox, C. L. (1978). The Industrial Relations Setting, Organisational Forces, and the Form and Content of Worker Participation. Academy of Management Review, 3(3), 572-583.

Koh, H. C., \& Boo, E. H. Y. (2001). The Link between Organisational Ethics and Job Satisfaction: A Study of Managers in Singapore. Journal of Business Ethics, 29(4), 309-324. http://dx.doi.org/10.1023/A:1010741519818

Koh, H. C., \& Boo, E. H. Y. (2004). Organisational Ethics and Employee Satisfaction and Commitment. Management Decision, 42(5/6), 677-693. http://dx.doi.org/10.1108/00251740410538514

Laczniak, G. R. (1983). Framework for Analysing Marketing Ethics. Journal of Macromarketing, 5, 7-17. http://dx.doi.org/10.1108/00251740410538514

Lum, L., Kervin, J., Klark, K., Reid, F., \& Sirola, W. (1998). Explaining Nursing Turnover Intent, Job Satisfaction, Pay Satisfaction, or Organizational Satisfaction? Journal of organizational Behaviour, 19, 305-320. http://dx.doi.org/10.1002/(SICI)1099-1379(199805)19:3<305::AID-JOB843>3.0.CO;2-N

McGee, G. W., \& Ford, R. C. (1987). Two (or More) Dimensions of Organizational Commitment: Re-examination of the Affective and Continuance Commitment Scales. Journal of Applied Psychology, 72(4), 638-642. http://dx.doi.org/10.1037/0021-9010.72.4.638

Meyer, J. P., \& Allen, N. J. (1984). Testing the "Side-Bet Theory" of Organizational Commitment: Some Methodological Considerations. Journal of Applied Psychology, 69(3), 372-378. http://dx.doi.org/10.1037/0021-9010.69.3.372

Meyer, J. P., \& Allen, N. J. (1991). A Three-Component Conceptualization of Organizational Commitment. Human Resource Management Review, 1(1), 61-89. http://dx.doi.org/10.1016/1053-4822(91)90011-Z

Meyer, J. P., \& Herscovitch, L. (2001). Commitment in the Workplace: Towards a General Model. Human Resource Management Review, 11, 299-326. http://dx.doi.org/10.1016/S1053-4822(00)00053-X

Meyer, J. P., Allen, N. J., \& Gellatly, I. R. (1990). Affective and Continuance Commitment to the Organization: Evaluation of Measures and Analysis of Concurrent and Time-Lagged Relations. Journal of Applied Psychology, 75(6), 710-720. http://dx.doi.org/10.1037/0021-9010.75.6.710

Meyer, J. P., Paunonen, S. V., Gellatly, I. R., Goffin, R. D., \& Jackson, D. N. (1989). Organizational Commitment and Job Performance: It's the Nature of the Commitment that Counts. Journal of Applied Psychology, 74, 152-156. http://dx.doi.org/10.1037/0021-9010.74.1.152

Morris, J. H., \& Sherman, J. D. (1981). Generalizability of an Organizational Commitment Model. Academy of Management Journal, 24(3), 512-526. http://dx.doi.org/10.2307/255572

Mowday, R. T. (1998). Reflections on the Study and Relevance of Organizational Commitment. Human Resource Management Review, 8(4), 387-401. http://dx.doi.org/10.1016/S1053-4822(99)00006-6

Mowday, R. T., Steers, R. M., \& Porter, L.W. (1979). The measurement of organizational Commitment. Journal of Vocational Behaviour, 14, 224-247. http://dx.doi.org/10.1016/0001-8791(79)90072-1

Nussbaum, B. (1986). The End of Corporate Loyalty. Business Week (August 4): 42-49.

Obalola, M. A. (2008). Beyond Philanthropy: Corporate Social Responsibility in the Nigerian Insurance Industry. Social Responsibility Journal, 4(4), 538-548. http://dx.doi.org/10.1108/17471110810909939

Ogunrinde, R. O. (1985). The Claim Settlement Provisions of the Nigerian Insurance Act, 1976. Journal of World Trade Law, 19(2), 170-178.

Peterson, D. K. (2003). The Relationship between Ethical Pressure, Relativistic Moral Beliefs and Organisational Commitment. Journal of Managerial Psychology, 18(6), 557-572. http://dx.doi.org/10.1108/02683940310494386

Porter, L. W., Crampon, W. J., \& Smith, F. J. (1976). Organizational Commitment and Managerial Turnover. Organizational Behaviour and Human performance, 15, 87-98. http://dx.doi.org/10.1016/0030-5073(76)90030-1 
Porter, L. W., Mowday, R. T., \& Boulin, P. V. (1974). Organisational Commitment, Job Satisfaction and Turnover among Psychiatric Technicians. Journal of Applied Psychology, 59(5), 603-609. http://dx.doi.org/10.1037/h0037335

Powell, D. M., \& Meyer, J. P. (2004). Side-Bet Theory and the Three-Component Model of Organizational Commitment. Journal of Vocational Behaviour, 36, 157-177. http://dx.doi.org/10.1016/S0001-8791(03)00050-2

Reicheld, F. R. (1996). The Loyalty Effect. Boston: Harvard Business School Press.

Robin, D. P., \& Reidenbach, R. E. (1987). Social Responsibility, Ethics, and Marketing Strategy: Closing the Gap between Concept and Application. Journal of Marketing 51(1), 44. http://dx.doi.org/10.2307/1251143

Rozen, I., De Pelsmacker, P., \& Bostyn, F. (2001). The Ethical Dimension of Decision Processes of Employees. Journal of Business Ethics, 33, 87-99. http://dx.doi.org/10.1023/A:1017536222355

Schwartz, M. (2001). The Nature of the Relationship between Corporate Codes of Ethics and Behaviour. Journal of Business Ethics, 32(3), 247-262. http://dx.doi.org/10.1023/A:1010787607771

Schwepker, Jr., C. H. (2001). Ethical Climate's Relationship to Job Satisfaction, Organisational Commitment, and Turnover Intention in the Salesforce. Journal of Business Research, 54, 39-52. http://dx.doi.org/10.1016/S0148-2963(00)00125-9

Sims, R. L., \& Kroeck, K. G. (1994). The Influence of Ethical Fit on Employee Satisfaction, Commitment and Turnover. Journal of Business Ethics, 13, 939-947. http://dx.doi.org/10.1007/BF00881663

Singhapakdi, A., Gopinath, M., Marta, J. K., \& Carter, L. L. (2008). Antecedents and Consequences of Perceived Importance of Ethics in Marketing Situations: A Study of Thai Businesspeople. Journal of Business Ethics, 81(4), 887-904. http://dx.doi.org/10.1007/s10551-007-9555-5

Solinger, O. N., Van Olffen, W., \& Roe, R. A. (2008). Beyond the Three-Component Model of Organizational Commitment. Journal of Applied Psychology, 93(1), 70-83. http://dx.doi.org/10.1037/0021-9010.93.1.70

Somers, M. J. (2001). Ethical Codes of Conduct and Organisational Context: A Study of the Relationship between Codes of Conduct, Employee Behaviour and Organisational Values. Journal of Business Ethics, 30(2), 185-195. http://dx.doi.org/10.1023/A:1006457810654

Sutherland, E., \& Cressey, D. R. (1970). Principles of Criminology ( $8^{\text {th }}$ edition). Chicago: Lippincott.

Thurstone, L. L. (1947). Multiple Factor Analysis. Chicago, University of Chicago.

Trevino, L. K. (1986). Ethical Decision-making in Organisations: A Person-Situation Interactionist Model. Academy of Management Review, 11(3), 601-617.

Valentine, S., \& Barnett, T. (2003). Ethics Code Awareness, Perceived Ethical Values and Organisational Commitment. Journal of Personal Selling \& Sales Management, 23(4), 359-367.

Victor, B., \& Cullen, J. B. (1988). The Organisational Bases of Ethical Work Climates. Administrative Science Quarterly, 33, 101-125. http://dx.doi.org/10.2307/2392857

Viswesvaran, C., Deshpande, S. P., \& Joseph, J. (1998). Job Satisfaction as a Function of Top Management Support for Ethical Behaviour: A Study of Indian Managers. Journal of Business Ethics, 17(4), 365-371. http://dx.doi.org/10.1023/A:1017956516324

Vitell, S. J., \& D. L. Davis (1990). Ethical Beliefs of MIS Professionals: The Frequency and Opportunity for Unethical Behaviour. Journal of Business Ethics 9(1), 63-70. http://dx.doi.org/10.1007/BF00382565

Vitell, S. J., \& Hidalgo, E. R. (2006). The Impact of Corporate Ethical Values and Enforcement of Ethical Codes on the Perceived Importance of Ethics in Business: A Comparison of U.S. and Spanish Managers. Journal of Business Ethics 64(1), 31. http://dx.doi.org/10.1007/s10551-005-4664-5

Vitell, S. J., \& Paolillo, J. G. P. (2004). A Cross-cultural Study of the Antecedents of the Perceived role of Ethics and Social Responsibility. Business Ethics: A European Review 13(2/3), 185-199. http://dx.doi.org/10.1111/j.1467-8608.2004.00362.x

Weeks, W. A., \& Nantel, J. (1992). Corporate Code of Ethics and Sales Force Behaviour: A Case Study. Journal of Business Ethics, 11: 753-760. http://dx.doi.org/10.1007/BF00872307

Wiener, Y. (1982). Commitment in Organizations: A Normative View. Academy of Management Review, 7(3), 418-428. 
Wotruba, T. R. (1990). A Comprehensive Framework for the Analysis of Ethical Behaviour, with a Focus on Sales Organisations. Journal of Personal Selling \& Sales Management, 10, 29-42.

\section{Notes}

Note 1. Heider (1946, p. 107-108) postulates that "An attitude towards an event can alter the attitude towards the person who caused the event, and, if the attitude towards a person and an event are similar, the event is easily ascribed to the person. A balanced configuration exists if the attitudes towards the parts of a causal unit are similar" (p. 107). He further broke this into two hypotheses: (a) "A balanced state exists if an entity has the same dynamic character in all possible respects". (b) "A balanced state exists if all parts of a units have the same dynamic character (i.e., if all are positive or all are negative), and if entities with different character are segregated from each other. If no balanced state exists, then forces towards this state will arise. Either the dynamic characters will change, or the unit relations will be changed through action or through cognitive reorganisation. If a change is not possible, the state of imbalance will produce tension" (pp. 107-108).

Note 2. Cited in Mowday (1998).

Table 1. Unrotated factor loadings for organisation commitment scale

\begin{tabular}{|c|c|}
\hline \multirow{2}{*}{ Item } & Unrotated Factors $^{\mathbf{a}}$ \\
\cline { 2 - 2 } & 1 \\
\hline 1 & 0.81 \\
\hline 2 & 0.78 \\
\hline 3 & 0.75 \\
\hline 4 & 0.59 \\
\hline
\end{tabular}

Note: ${ }^{a} 1$ factor extracted through PCA

The table shows the results of the factor analysis, the dimensionality and the factor loading of the organizational commitment scale.

Table 2. Unrotated and rotated factor loadings of CEV

\begin{tabular}{|c|c|c|c|c|c|}
\hline Item & \multicolumn{2}{|c|}{ Unrotated Factors $^{\mathbf{a}}$} & Item & \multicolumn{2}{c|}{ Rotated Factors $^{\mathbf{b}}$} \\
\hline & 1 & 2 & & 1 & 2 \\
\hline 1 & 0.24 & 0.85 & 1 & 0.05 & 0.88 \\
\hline 2 & 0.17 & 0.86 & 2 & -0.17 & 0.88 \\
\hline 3 & 0.80 & -0.11 & 3 & 0.80 & 0.07 \\
\hline 4 & 0.80 & -0.24 & 4 & 0.83 & -0.06 \\
\hline 5 & 0.66 & -0.11 & 5 & 0.67 & 0.03 \\
\hline
\end{tabular}

Note: ${ }^{a} 2$ factors extracted

${ }^{\mathrm{b}}$ Rotation converge in 4 iterations

The table shows the results of the factor analysis, the factorial structure, the rotated and unrotated factor loading of the Corporate Ethical Value scale. It also indicated the number of iterations to achieve convergence of the rotated factors. 
Table 3. Descriptive statistics and correlations between commitment and the predictor variables

\begin{tabular}{|c|c|c|c|c|c|c|c|c|c|c|}
\hline Construct & 1 & 2 & 3 & 4 & 5 & 6 & Mean & $\mathrm{SD}$ & $\alpha$ & $\mathrm{N}$ \\
\hline $\begin{array}{l}\text { 1.Organizational } \\
\text { Commitment }\end{array}$ & 1 & & & & & & 12.99 & 4.39 & .71 & 413 \\
\hline $\begin{array}{l}\text { 2. Top } \\
\text { Management }\end{array}$ & $\begin{array}{c}-0.346 \\
* *\end{array}$ & 1 & & & & & 14.60 & 3.14 & .65 & 414 \\
\hline $\begin{array}{l}\text { 3. Managers } \\
\text { acting ethically }\end{array}$ & $\begin{array}{c}0.197 \\
* *\end{array}$ & 0.034 & 1 & & & & 8.40 & 2.83 & .72 & 415 \\
\hline 4. Age & $\begin{array}{c}0.112 \\
*\end{array}$ & -0.013 & -0.024 & 1 & & & 1.98 & 0.63 & - & 412 \\
\hline $\begin{array}{l}\text { 5. Length of } \\
\text { Service }\end{array}$ & 0.080 & -0.041 & -0.083 & $\begin{array}{c}0.481 \\
* *\end{array}$ & 1 & & 2.81 & 1.26 & - & 410 \\
\hline $\begin{array}{l}\text { 6. Position in } \\
\text { organization }\end{array}$ & $\begin{array}{c}-0.135 \\
* *\end{array}$ & -0.067 & -0.064 & $\begin{array}{c}-0.364 \\
* *\end{array}$ & $\begin{array}{c}-0.315 \\
* *\end{array}$ & 1 & 2.33 & 0.69 & - & 410 \\
\hline
\end{tabular}

Note: $* \mathrm{p}<0.05$ (2-tailed) $\quad * * \mathrm{p}<0.01(2$-tailed)

The table shows the descriptive statistics of the focal, demographic (control) variables and the internal consistency of the scales as measured cronbach alpha.

Table 4. Multiple regression analysis - Model 1

\begin{tabular}{|l|c|c|c|}
\hline Variable & $\beta$ & T value & Sig. of $T$. \\
\hline $\begin{array}{l}\text { Organizational } \\
\text { Commitment }\end{array}$ & & & 0.000 \\
\hline $\begin{array}{l}\text { Top Management } \\
\text { Support for Ethics }\end{array}$ & -0.353 & -7.798 & 0.000 \\
\hline $\begin{array}{l}\text { Managers are Acting } \\
\text { Ethically }\end{array}$ & 0.209 & 4.615 & \\
\hline R squared $=\mathbf{0 . 1 6 3}$, Adjusted R Squared $=\mathbf{0 . 1 5 9}, \boldsymbol{F}=\mathbf{3 9 . 8 7}$, Sig. of $\boldsymbol{F}=\mathbf{0 . 0 0 0}$ \\
\hline
\end{tabular}

Note: The table shows the regression results of the model 1 which hypothesized corporate ethical values as a significant predictor of organizational commitment. It also indicates the model fitness as shown by the R squared, $\mathrm{F}$ value and significance of $\mathrm{F}$.

Table 5. Multiple regression analysis - Model 2

\begin{tabular}{|c|c|c|c|}
\hline Variable & $\beta$ & Tvalue & Sig. of $T$. \\
\hline \multicolumn{4}{|c|}{ Organizational Commitment - Model $2 a$} \\
\hline Age & 0.073 & 1.297 & 0.195 \\
\hline Length of Service & -0.008 & -0.140 & 0.889 \\
\hline Position & -0.086 & -1.704 & 0.089 \\
\hline \multicolumn{4}{|c|}{$R^{2}=0.014$, Adjusted $R^{2}=0.007, R^{2}$ Change $=0.014, F=1.908$, Sig. of $F=0.128$} \\
\hline \multicolumn{4}{|c|}{ Organizational Commitment - Model $2 \boldsymbol{b}$} \\
\hline $\begin{array}{l}\text { Top Management } \\
\text { Support for Ethics }\end{array}$ & -0.356 & -7.836 & 0.000 \\
\hline $\begin{array}{l}\text { Managers are Acting } \\
\text { Ethically }\end{array}$ & 0.208 & 4.491 & 0.000 \\
\hline Age & 0.082 & 1.158 & 0.115 \\
\hline Length of Service & 0.011 & 0.214 & 0.831 \\
\hline Position & -0.075 & -1.620 & 0.106 \\
\hline
\end{tabular}

Note: The table shows the regression results of the model 2 which assesses the relative predictive power of the focal variables in conjunction with the control variables. The table also indicates the model fitness as shown by the $\mathrm{R}$ squared, $\mathrm{F}$ value and significance of $\mathrm{F}$. 